\title{
Effects of Waste Disposal: Temporo-Spatial Patterns of Bacterial Community Composition on Oyster Farms in Estuary Regions of Bahia, Brazil
}

\author{
Maíra Pessoa Jornane Barbosa Santos ${ }^{1}$, Jorge Raimundo Lins Ribas ${ }^{2}$, Carlos Eduardo Crispim de Oliveira Ramos ${ }^{1}$, \\ Rodrigo Diana Navarro ${ }^{3}$, Denise Soledade Peixoto Pereira ${ }^{1} \&$ Rodrigo Fortes da Silva ${ }^{1}$ \\ 1 Center of Agricultural Sciences, Environmental and Biological, Faculty of Fish Engineering, Federal \\ University of Bahia, Campus Cruz das Almas, Bahia, Brazil \\ ${ }^{2}$ Agricultural Defense Agency of Bahia, Salvador, Bahia, Brazil \\ ${ }^{3}$ Faculty of Agronomy and Veterinary, University of Brasília, Campus Darcy Ribeiro, Brasília, DF, Brazil \\ Correspondence: Rodrigo Fortes da Silva, Laboratory of Feeding Behavior and Fish Nutrition, Center of \\ Agricultural Sciences, Environmental and Biological, Faculty of Fish Engineering, Federal University of Bahia, \\ Campus Cruz das Almas, Bahia, Brazil. E-mail: fortes@ufrb.edu.br
}

\begin{tabular}{|c|c|c|}
\hline Received: July 2, 2017 & Accepted: September 10, 2017 & Online Published: January 15,2018 \\
\hline doi:10.5539/jas.v10n2p178 & URL: https://doi.org/10 & s.v10n2p178 \\
\hline
\end{tabular}

\begin{abstract}
Oyster farming in Brazil is limited by a number of problems, such as lack of sanitary control in production areas. The aim of the present study was to use the multiple correspondence analyses (MCA) to correlate the microbiological quality of oyster production in the state of Bahia, Brazil, by linking it to environment parameters. Samples were randomly collected from 15 different oyster farms, from two different cultivation techniques (lantern and pillow baskets), corresponding dry and rainy periods. Twenty eight samples were collected, stored at $5{ }^{\circ} \mathrm{C}$ and send to the laboratory. The analyzed environmental parameters were $\mathrm{pH}$, temperature, dissolved oxygen, salinity, and polluting sources like sewage outflow. Coliforms were counted at $35{ }^{\circ} \mathrm{C}$ and $45{ }^{\circ} \mathrm{C}$ : Escherichia coli, Salmonella sp., Pseudomonas sp. and Aeromonas sp. Statistical analyzes were performed using the data sizing reduction procedure (MCA), through the SPPS Program, version 18.0. A positive relationship was found between the dry period and lantern net farming with poor sanitary conditions. MCA allowed the analyzed commercial oyster farms to form three distinct groups, helped define the intervention strategies of these commercial oyster farms and provided the basis for implementing health protection measures.
\end{abstract}

Keywords: ecosystem model, estuaries; shellfish aquaculture, multivariate analysis

\section{Introduction}

Artisanal oyster farming is a very important way to provide the local community with food and a livelihood (Soares et al., 2011). It is estimated that thousands of people along the country's coastline directly or indirectly depend on this shellfish. However, its production and marketing are handled inappropriately, and often pose severe health risks for consumers (Evangelista-Barreto, 2006).

Oysters are filter feeders and are capable of accumulating various types of organic and inorganic substances which may be present in the environment (Silva et al., 2004). There are two major groups of bacteria that can contaminate seafood products. The first group is formed by the bacteria naturally present in the aquatic environment, namely: Clostridium botulinum, Listeria monocytogenes, Vibrio spp. and Aeromonas hydrophila as one group. The second group contains coliforms, whose presence indicates water contamination by human waste (Evangelista-Barreto, 2006; Christo et al., 2008). Therefore, the sanitary standards of such products depend directly on water quality (Silva et al., 2004). Similarly in the state of Bahia, different types of culture techniques are employed in estuarine regions, but are strongly affected by changes in environmental parameters and different sources of contamination. Statistical tools could provide interesting information to save time and financial resources.

A multiple correspondence analysis (MCA) is an analytical technique for exploratory data, which was developed to identify the systematic relations between variables when there are no (a priori) expectations about the nature 
of the relationship among them (Beh, 2004). For example, by means of an MCA analysis, it has been possible to point out the occurrence of an atypical event responsible for disrupting the seasonal cycle, but is responsible for the massive mortality of benthos on shellfish farms (Mazouni et al., 1996). This tool was used to identify the origin of fecal pollution in bathing and shellfish harvesting waters (Gourmelon et al., 2010), and the distribution patterns of foraminiferal assemblages in relation to trace metals, sediment grain size and calcium carbonate (Li et al., 2015).

This study aimed to identify and quantify the bacterial density distribution on oyster farms in the state of Bahia (Brazil) by establishing a relationship between environmental parameters and considering an area affected by waste pollutants using data from the Brazilian Institute of Geography and Statistics (IBGE, 2013) with native oyster farming systems (Crassostrea sp.) and cultivation periods by an MCA.

\section{Materials and Methods}

\subsection{Sample Collection}

This study was conducted in strict accordance with the recommendations in the Guide for the National Council for Animal Experiments Control (CONCEA). Oysters were immediately numbed with ice so they suffered no pain or discomfort during animal procedures (Silva et al., 2004).

The study was conducted on oyster farms in the State of Bahia, a major tourist area in Brazil. Fifteen farms were evaluated from seven different towns, representing the totality (Table 1).

Table 1. Coordinates of the oyster farms studied on the Bahia-Brazil coast for sample collection

\begin{tabular}{llll}
\hline Acronym & Farm & Latidude & Longitude \\
\hline A & Taperoá & $13^{\circ} 32^{\prime} 13^{\prime \prime}$ & $09^{\circ} 39^{\circ} 29^{\prime \prime}$ \\
B & Graciosa & $13^{\circ} 28^{\prime} 44^{\prime \prime}$ & $39^{\circ} 5^{\prime} 33^{\prime \prime}$ \\
C & Iguape & $12^{\circ} 39^{\prime} 11^{\prime \prime}$ & $38^{\circ} 51^{\prime} 54^{\prime \prime}$ \\
D & Dendê & $12^{\circ} 39^{\prime} 27^{\prime \prime}$ & $38^{\circ} 51^{\prime} 17^{\prime \prime}$ \\
E & Baiacú & $12^{\circ} 39^{\prime} 27^{\prime \prime}$ & $38^{\circ} 51^{\prime} 17^{\prime \prime}$ \\
F & Maratandiba & $13^{\circ} 0^{\prime} 9^{\prime \prime}$ & $0,38^{\circ} 45^{\prime} 59^{\prime \prime}$ \\
G & $13^{\circ} 0^{\prime} 24^{\prime \prime}$ & $0,38^{\circ} 43^{\prime} 32^{\prime \prime}$ \\
H & Ponta Grossa & $13^{\circ} 0^{\prime} 9^{\prime \prime}$ & $38^{\circ} 45^{\prime} 59^{\prime \prime}$ \\
I & Tanque & $13^{\circ} 57^{\prime} 48^{\prime \prime}$ & $39^{\circ} 2^{\prime} 55^{\prime \prime}$ \\
J & Porto do Campo & $13^{\circ} 57^{\prime} 49^{\prime \prime}$ & $39^{\circ} 2^{\prime} 55^{\prime \prime}$ \\
L & Batateira & $38^{\circ} 59^{\prime} 36^{\prime \prime}$ \\
M & Pedrinhas & $13^{\circ} 32^{\prime} 25^{\prime \prime}$ & $38^{\circ} 59^{\prime} 18^{\prime \prime}$ \\
$\mathrm{N}$ & Canavieirinhas & $13^{\circ} 33^{\prime} 40^{\prime \prime}$ & $38^{\circ} 59^{\prime} 34^{\prime \prime}$ \\
O & Tapuias & $13^{\circ} 34^{\prime} 7^{\prime \prime}$ & $38^{\circ} 59^{\prime} 34^{\prime \prime}$ \\
P & Turinhas & $13^{\circ} 34^{\prime} 7^{\prime \prime}$ & $39^{\circ} 0^{\prime} 40^{\prime \prime}$ \\
\hline
\end{tabular}

Oysters were collected between May 2013 and November 2014. The following parameters for sanitary classification were considered for the MCA according to the Brazilian Institute of Environment and Water Resources, INEMA: two periods, one was P1, a dry season (January, March, May, June, July, October and December) and the other was P2, a rainy season (February, April, August, September and November). Two different culture techniques were employed: lantern nets and pillow baskets (Table 2). The pollution factors at the aquaculture sites (organic matter, agricultural waste outflows, sewage and industrial waste) and their effects on the bacterial contamination samples were considered. In order to consider an area affected by waste pollutants, data from the Brazilian Institute of Geography and Statistics (IBGE, 2013) were employed. Test samples consisted in whole oyster muscle. Samples were obtained from the aquatic environment randomly by covering five collection points in the same aquaculture area (Silva et al., 2004). Twenty-eight collections, divided between periods $\mathrm{P} 1$ and $\mathrm{P} 2$, were obtained, and were placed in refrigerated thermoplasts $\left(5^{\circ} \mathrm{C}\right)$, and taken alive to the laboratory (State Agency of Animal Health and public health/ADAB, Salvador/Brazil). For each collection, abiotic parameters (temperature, salinity, $\mathrm{pH}$ and dissolved oxygen-OD) were measured with a Lutron ${ }^{\circledR}$ probe (Indiana, USA). 


\subsection{Microbiological Analyses}

The methodology followed the parameters of the "Compendium of Methods for the Microbiological Examination of foods" of the American Public Health Association (Apha, 2001). The oysters were washed with tap water and opened aseptically. Samples were weighed and homogenized in a blender with $450 \mathrm{~mL}$ of sterilized saline solution $(0.85 \%)$, corresponding to a $10^{-1}$ dilution (Silva et al., 2004). The most probable number (MPN) of coliforms at $45-35{ }^{\circ} \mathrm{C}$ was estimated by the 5-tube method according to Bergey's Manual of Systematic Bacteriology (Brenner, 1984). The following microorganisms were evaluated: Salmonella spp., positive coagulase Staphylococcus, Escherichia coli, Pseudomonas sp., Aeromonas spp. (Silva et al., 2004).

\subsection{Statistical Analysis}

A multivariate analysis process, used to reduce data set dimensions, an MCA, and an ascending hierarchical classification (AHC) were run to classify the variables. By subjecting the oyster farms to an AHC, it was possible to form a typology of the first two dimensions of the MCA performed with the original variables. Mathematical definitions for both methods and the iterative model for the MCA are found in detail in Lebart et al. (1995). Statistical analyses were carried out by data dimensionality reduction procedures (MCA) with SPSS ${ }^{\circledR}$, version 18.0. For these analyses, 44 variables were used and the levels of each description are listed in Table 2.

Table 2. List of selected variables for the sanitary classification of the oyster farms submitted to an MCA and their occurrence levels

\begin{tabular}{|c|c|}
\hline Variables & Levels description \\
\hline \multirow[t]{2}{*}{ Period } & P1 = dry season: January, March, May, June, July, October and December \\
\hline & $\mathrm{P} 2$ = rainy season: February, April, August, September and November \\
\hline \multirow[t]{2}{*}{ Culture technique } & Lantern nets $=$ Suspended culture \\
\hline & Pillow baskets $=$ Beach culture \\
\hline \multirow[t]{2}{*}{ Sanitary clasification ${ }^{1}$} & yes $=$ Fit for consumption, present or higher than the limit ${ }^{1}$ \\
\hline & No $=$ Not good for consumption, absent or lower than the limit ${ }^{1}$ \\
\hline \multirow[t]{2}{*}{ Outflow of agricultural waste } & Yes $=$ Presence \\
\hline & No $=$ Absence \\
\hline \multirow[t]{2}{*}{ Outflow of industrial residues ${ }^{2}$} & Yes $=$ Presence \\
\hline & No $=$ Absence \\
\hline \multirow[t]{2}{*}{ Residues sources and organic matter } & Yes $=$ Presence \\
\hline & No $=$ Absence \\
\hline \multirow[t]{2}{*}{ Outflow of sewage } & Yes $=$ Presence \\
\hline & No $=$ Absence \\
\hline
\end{tabular}

A binomial logit GLM was used to test the effect of the cultivation technique on oyster suitability for human consumption.

\section{Results}

\subsection{Sample Results}

The estimated most probable number (MPN) value ranges of coliforms and bacterial analyses (UFC/g) are shown in Table 3. Aeromonas sp. or Pseudomonas sp. was not found in the samples, and Salmonella sp. was detected only at site $\mathrm{J}$ (see Tables 1 and 3). 
Table 3. Microbiological results determined in oyster muscle (Crassostrea sp.) for oyster farms in Bahia, Brazil

\begin{tabular}{|c|c|c|c|c|c|c|c|}
\hline Farms $^{1}$ & $\begin{array}{l}\text { Coliformes at } 35^{\circ} \\
\text { MPN }\end{array}$ & $\begin{array}{l}\text { Coliformes at } 45^{\circ} \\
\text { MPN }\end{array}$ & $\begin{array}{l}\text { Staphylococcus } \\
\text { UFC/g }\end{array}$ & $\begin{array}{l}\text { E. coli } \\
\text { MPN }\end{array}$ & $\begin{array}{l}\text { Salmonella } \\
\text { UFC/g }\end{array}$ & $\begin{array}{l}\text { Aeromonas } \\
\mathrm{UFC} / \mathrm{g}\end{array}$ & $\begin{array}{l}\text { Pseudomonas } \\
\text { UFC/g }\end{array}$ \\
\hline \multirow[t]{2}{*}{$\mathbf{A}$} & $2.4 \times 10^{2}$ & $2.9 \times 10$ & $<1 \times 10$ & $<1 \times 10$ & - & - & - \\
\hline & 3 & $2.8 \times 10$ & $<1 \times 10$ & $<1 \times 10$ & - & - & - \\
\hline \multirow[t]{3}{*}{ B } & $2.9 \times 10$ & $2.9 \times 10$ & $1 \times 10$ & $<1 \times 10$ & - & - & - \\
\hline & $1.1 \times 10^{4}$ & 9 & - & $<1 \times 10$ & - & - & - \\
\hline & $>2.4 \times 10^{3}$ & $<3$ & $10^{3}$ & $<1 \times 10$ & - & - & - \\
\hline \multirow[t]{2}{*}{ C } & $1.4 \times 10$ & $<3$ & $5 \times 10^{2}$ & $<1 \times 10$ & - & - & - \\
\hline & $4.3 \times 10$ & $<3$ & $<1 \times 10$ & $<1 \times 10$ & - & - & - \\
\hline D & 3.6 & $<3$ & $<1 \times 10$ & $<1 \times 10$ & - & - & - \\
\hline \multirow[t]{2}{*}{$\mathbf{E}$} & $2.3 \times 10$ & 9 & $<1 \times 10$ & $<1 \times 10$ & - & - & - \\
\hline & 4 & 4 & - & $<1 \times 10$ & - & - & - \\
\hline \multirow[t]{2}{*}{ F } & $14.3 \times 10$ & 9 & $<1 \times 10$ & $<1 \times 10$ & - & - & - \\
\hline & 4 & $<3$ & - & $<1 \times 10$ & - & - & - \\
\hline $\mathbf{G}$ & 4 & $<3$ & $<1 \times 10$ & $<1 \times 10$ & - & - & - \\
\hline \multirow[t]{2}{*}{$\mathrm{H}$} & $4.3 \times 10$ & 9 & $1 \times 10$ & $<1 \times 10$ & - & - & - \\
\hline & $4.3 \times 10$ & 9 & $4.3 \times 10$ & $<1 \times 10$ & - & - & - \\
\hline \multirow[t]{2}{*}{ I } & 2.3 & 4 & $<1 \times 10$ & - & - & - & - \\
\hline & $2.3 \times 10$ & 4 & $<1 \times 10$ & - & - & - & - \\
\hline \multirow[t]{2}{*}{$\mathbf{J}$} & $4.3 \times 10$ & $2.3 \times 10$ & $<1 \times 10$ & - & - & - & - \\
\hline & $>2.4 \times 10$ & $9 / 25$ & $<1 \times 10$ & - & + & - & - \\
\hline \multirow[t]{2}{*}{ L } & $1.5 \times 10^{2}$ & $<3.0$ & $5 \times 10^{3}$ & - & - & - & - \\
\hline & $>2.4 \times 10^{3}$ & $6.4 \times 10$ & $>1 \times 10$ & - & - & - & - \\
\hline \multirow[t]{2}{*}{ M } & $1.1 \times 10^{3}$ & $9.3 \times 10$ & $1 \times 10$ & - & - & - & - \\
\hline & $1.1 \times 10^{3}$ & $7.5 \times 10$ & $<1 \times 10$ & - & - & - & - \\
\hline \multirow[t]{2}{*}{$\mathbf{N}$} & $2.4 \times 10^{2}$ & 4 & $<1 \times 10$ & - & - & - & - \\
\hline & $2.3 \times 10$ & 4 & $<1 \times 10$ & - & - & - & - \\
\hline \multirow[t]{2}{*}{ O } & $>2.4 \times 10^{3}$ & $4.6 \times 10$ & $<1 \times 10$ & - & - & - & - \\
\hline & $4.6 \times 10^{2}$ & 4 & $<1 \times 10$ & - & - & - & - \\
\hline $\mathbf{P}$ & 4 & $<3$ & - & - & - & - & - \\
\hline
\end{tabular}

Note. ${ }^{1}$ Oyster farms sampled in the Bahia state/Brazil. Results represented as (-) means microorganism not found and $(+)$ microorganism found.

The counts of coagulase positive Staphylococci in the oyster samples ranged from 0 to $5 \times 10^{3} \mathrm{CFU} / \mathrm{g}$. The limit established by ANVISA (2001) was $10^{3} \mathrm{CFU} / \mathrm{g}$. E. coli strains were isolated from eight of the 15 study sites $(53 \%)$. The coliform counts (at $45^{\circ} \mathrm{C}$ ) in the surveyed oysters ranged from $<3 / \mathrm{g}$ to $7.5 \times 10 / \mathrm{g}$. Of the 28 analyzed samples, 7\% presented counts above the standards set by legislation (ANVISA, 2001). Coliforms (at $35^{\circ} \mathrm{C}$ ) ranged from 2.3 to $>2.4 \times 10^{3} / \mathrm{g}$.

\subsection{MCA}

Groups with the same characteristics were formed from the data collected on the farms that participated. The variables linked to the study sites, with their contributions and correlations, are illustrated in Figure 1. 


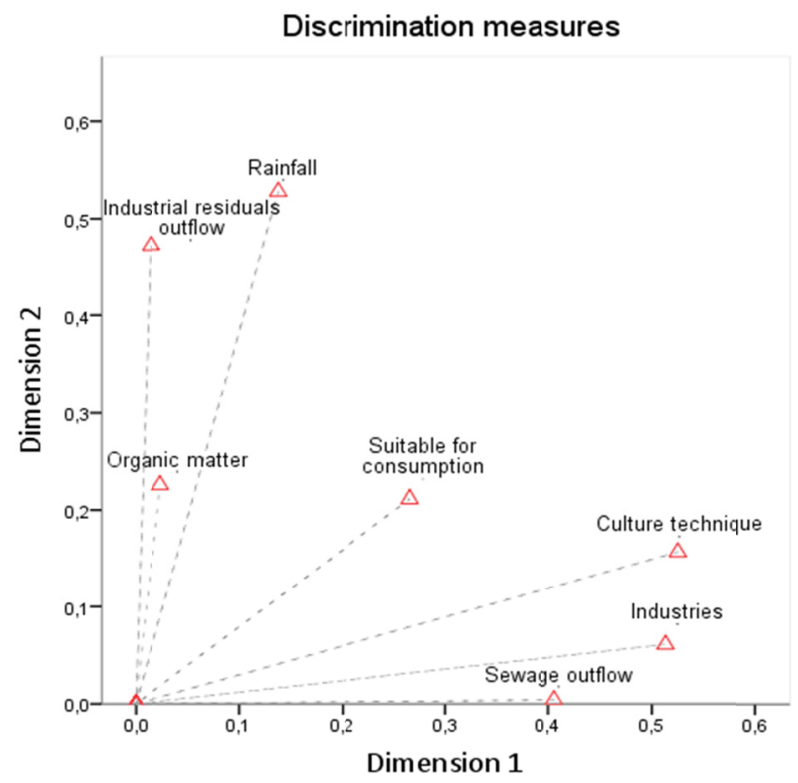

Figure 1. MCA ordination diagram of the environmental variables at the oyster production sites, represented with two dimensions and their contributions to the MCA analysis, with: period; culture technique; sanitary classification, sewage outflow, industrial residue outflow; agricultural waste outflow and residue sources, plus organic matter

The variables that contributed most as explained variance (inertia) were those with the highest inertia values for each dimension. Values + or - attributed to every variable in each dimension, and indicated the importance of each one in the discriminating farm oyster groups as regards the studied characteristics. Variables sewage outflow, industrial residue outflow, culture technique and sanitary classification contributed the most to the formation of the first dimension, which contributed to $31 \%$ of the inertia according to the MCA analysis. Dimension 2 associated agricultural waste outflow, presence of residue sources and organic matter and period. This dimension was responsible for $24 \%$ of the inertia. The nonparametric correlations between variables are shown in Table 4.

Table 4. Correlation analysis between the variables transformed into MCA

\begin{tabular}{lllllll}
\hline & $\mathrm{P}^{1}$ & $\mathrm{CT}^{2}$ & $\mathrm{SC}^{3}$ & $\mathrm{~S}^{4}$ & $\mathrm{I}^{5}$ & $\mathrm{~A}^{6}$ \\
\hline $\mathrm{P}^{1}$ & 1 & & & & & \\
$\mathrm{CT}^{2}$ & -0.022 & 1 & & & & \\
$\mathrm{SC}^{3}$ & 0.331 & 0.31 & 1 & & & \\
$\mathrm{~S}^{4}$ & 0.227 & 0.126 & 0.181 & 1 & & \\
$\mathrm{I}^{5}$ & 0.067 & 0.503 & -0.009 & 0.372 & 1 & \\
$\mathrm{~A}^{6}$ & -0.228 & 0.266 & -0.097 & 0.113 & -0.037 & 1 \\
$\mathrm{RSOM}^{7}$ & -0.101 & 0.173 & 0.013 & 0.312 & -0.101 & 0.826 \\
Dimension & 1 & 2 & 3 & 4 & 5 & 6 \\
Value & 1.862 & 1.434 & 0.994 & 0.891 & 0.577 & 0.241 \\
\hline
\end{tabular}

Note. ${ }^{1}$ Period; ${ }^{2}$ Culture technique; ${ }^{3}$ Sanitary classification; ${ }^{4}$ Outflow of sewage; ${ }^{5}$ Outflow of industrial residues; ${ }^{6}$ Outflow of agricultural waste; ${ }^{7}$ Residues sources and organic matter.

The multivariate correlation indicated that residue sources and organic matter correlated highly with agricultural waste outflow (0.826). This analysis also showed the high correlation of the culture technique associated with presence of industries $(0.503)$. However, the other characteristics were poorly correlated.

The associations between categories of variables and formation of clusters were evaluated by analyzing the proximity between the points in Figure 2A. 


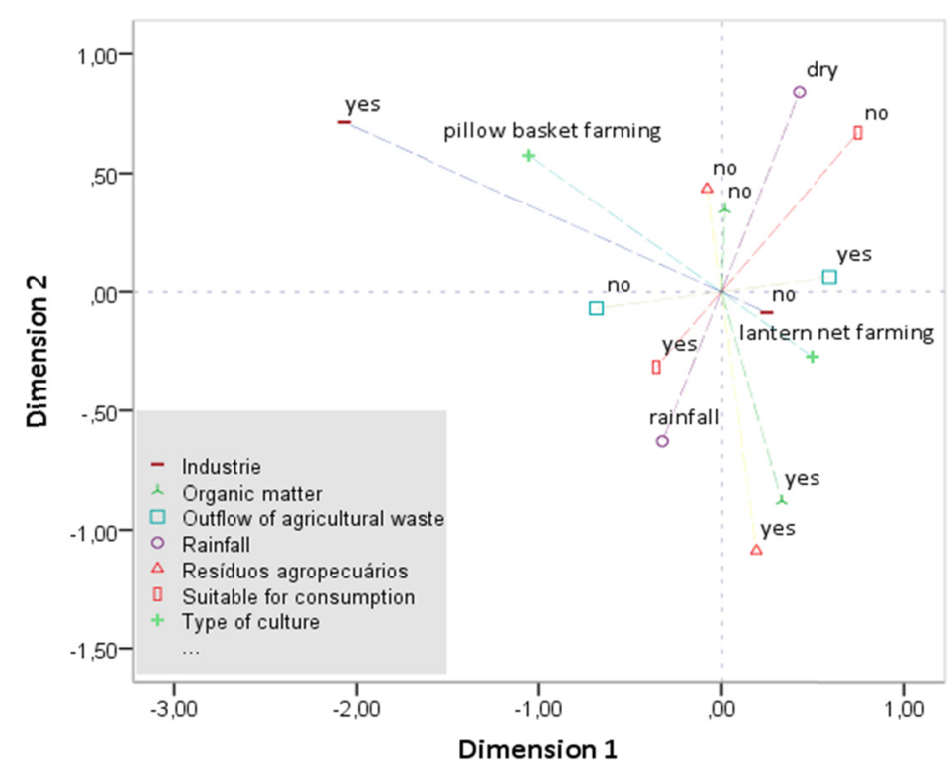

Figure 2A. Cluster typology analysis: relationship of cultivation type (pillow baskets or lantern net) and oyster production period (rainy or dry) with environmental parameters (agricultural waste outflow, organic matter, industrial residue and local industries). The analysis also compared if the oysters produced under these different conditions were suitable for human consumption according to microbial analyses. Positive or negative signals inside a quadrant meant a close or distant relationship between cultivation sites

These variables were organized into three oyster farm groups (G1-G3) according to the MCA analysis and are represented by different colors (Figure 2B).

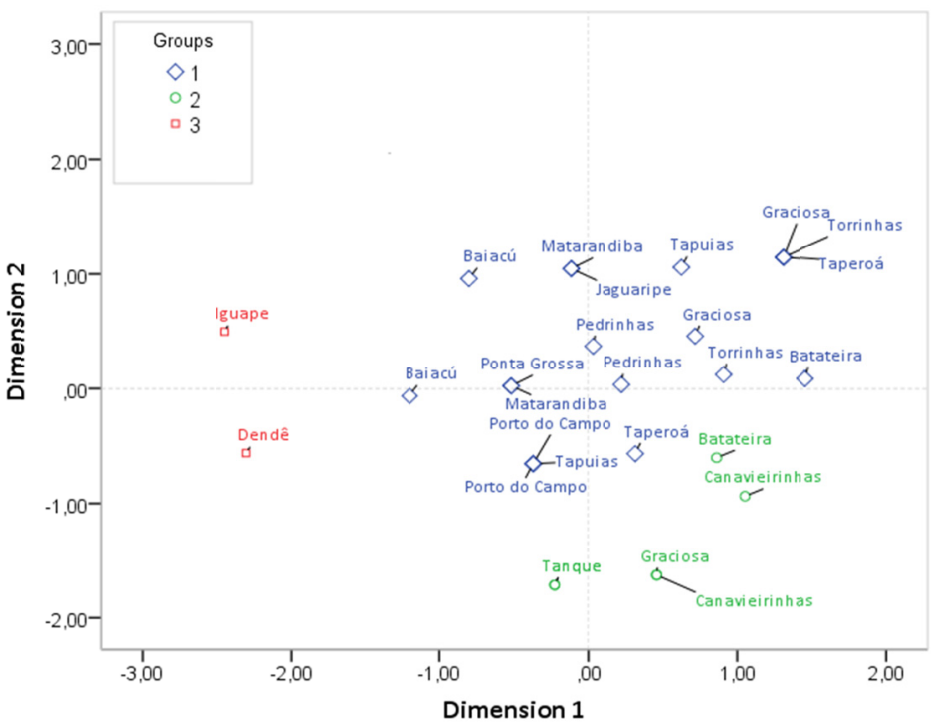

Figure 2B. MCA: grouping the oyster production sites according to common characteristics. The same color means they had the same characteristics (cultivation type, oyster production period and environmental parameters). A symbol associated with more than one name means that it was the same cultivation area

The farm culture techniques type "pillow basket" is characterized by being located in an industrial region. The oysters produced during period P1 (January, March, May, June, July, October and December) were classified as unfit for human consumption. However, we observed that the oysters produced at the same site, but during period P2 (February, April, August, September and November), were fit for human consumption. G1 consisted 
in $67.86 \%$ of the analyzed properties, and 13 of the 19 farms in this group used lantern nets for oyster production purposes. According to the MCA analysis, the strong presence of coliforms at $45{ }^{\circ} \mathrm{C}$, Salmonella sp. and E. coli were associated with this group characteristic. The mean temperature measured at the sites in this group was $29.13{ }^{\circ} \mathrm{C}$, mean dissolved oxygen was $3.29, \mathrm{pH}$ was 7.38 and salinity was $18.26 \mathrm{ppm}$. The period was mixed with P1 slightly predominating (52.63\%). In this group, $63.16 \%$ of the oyster farms produced oysters that were classified as unfit for human consumption.

G2 is characterized primarily by using "lantern nets" for oyster production, and by having an agricultural waste outflow $(100 \%)$ and a sewage outflow $(66 \%)$. The MCA grouped the oysters from this group in P2. The water parameters in this group were temperature $\left(26.42 \pm 1{ }^{\circ} \mathrm{C}\right)$, dissolved oxygen $(5.15 \mathrm{mg} / \mathrm{L}), \mathrm{pH}(5.5)$ and salinity $(16.07 \mathrm{ppm})$. Of this cluster, $84 \%$ was characterized as being fit for human consumption.

The properties of G3 are characterized by having pillow-type cultures (100\%) and being classified as being fit for human consumption $(100 \%)$. However, the value obtained for industrial residue outflows was $100 \%$. The average salinity of the properties of this group was $19.85 \mathrm{ppm}$, while $\mathrm{pH}$ was 7.28 , temperature was $24.3 \pm 1{ }^{\circ} \mathrm{C}$ and dissolved oxygen was $4.84 \mathrm{mg} / \mathrm{L}$.

After characterizing group, the MCA analysis indicated no correlations between the abiotic parameters $(\mathrm{pH}$, temperature, DO and salinity) and any of the seven listed variables $(\mathrm{P}>0.001)$. A relation was found between high bacterial populations with the "months" period of oyster cultivation. However, the lantern nets technique for oyster production had an effect $(\mathrm{P}<0.001)$, which was expressed in the oyster classification as being unfit for human consumption according to the binomial logit GLM analysis.

\section{Discussion}

Our results agree with those reported by Edwards et al. (1999) as the proportion of bacterial populations was higher during the dry season; e.g. January. Unlike our results, Pujalte et al. (1999) found a larger bacterial population associated with Mediterranean oysters $(O$. edulis $)$ in warmer months. These results may be due to the effect of temperature, rainfall or dry period, and to a change in the water parameters. However, we found no correlation for $\mathrm{pH}$, temperature and salinity with bacterial populations. Bacterial and archaeal populations correlated with conductivity and rainfall (Edwards et al., 1999). In a study that assessed the seasonal distribution of Vibrio parahaemolyticus in oysters in SW India, Deepanjali el al. (2005) found that temperature was the most relevant factor for the seasonal and geographical distribution of this pathogen, which did not vary very much in tropical regions during the year. So other parameters, such as salinity, must be taken into account.

The positive relationship between the lantern nets technique and microbiological findings may be related to the constant flooding that occurs in this cultivation type (Evans \& Langdon, 2006), which facilitates filtration and subsequent exchanges between oysters and its environment. Lantern nets should be used in deep water locations where strong currents are rare (Yang et al., 2006) and water renewal in these places is poor, especially in relation with contamination sources that may interfere with the sanitary quality of these animals. So legislation should also take into account several parameters like biological, chemical and physical parameters (Gourmelon et al., 2010; Santos et al., 2011; Silva et al., 2004).

Presence of E. coli and coliforms at G1 highlighted the poor water quality of the bivalve products in this region. Heavy tourism development, associated with the sites in this region, indicates the need to use a treatment system with the oysters produced there. Hence the presence of this microorganism in $53 \%$ of the studied samples indicated the health risk associated with not only eating oysters, but also with eating other marine products from a contaminated area. Even though E. coli has been isolated from eight sites, its presence at levels $<230 \mathrm{MPN}$ per 100 grams of edible portion was considered fit for human consumption according to the MPA (2012). Presence of coliforms at $45^{\circ} \mathrm{C}$ in the $\mathrm{G} 1$ oysters suggested a high water pollution level caused by sewage waste (Barros et al., 2005). When researching the incidence of fecal indicator bacteria that grew in oysters in saline waters from sea farms in Baía Sul on the Santa Catarina's Island, Brazil, Ramos et al. (2010) found coliforms with a $35{ }^{\circ} \mathrm{C}$ variation of $<1.8$ to $>1.6 \times 10^{3} \mathrm{MPN} / 100 \mathrm{ml}$. However, the present study assessed bacteriological quality directly in oyster samples. Assessing shellfish quality is more important than water analyses (Oliveira et al., 2014). Current Brazilian law only requires the evaluation of coliforms at $45{ }^{\circ} \mathrm{C}$ in cooked and processed mollusks. It is worth emphasizing that most of these mollusks are consumed raw and do not undergo any treatment. This indicates the deficiency of current law, which is lacking in the health education area, particularly when it comes to warning potential consumers and making them aware of the danger or risk inherent to eating raw oysters. In a survey about pollution done on the River Cachoeira in the state of Bahia, Sande et al., (2010) isolated 10 species of microorganisms from mangrove oysters, including Salmonella sp., E. coli and Shigella sp. 
The authors warned about the risk of consuming these mollusks in natura, even though they fell within the legal limits since many of the pathogens they found were dispensed.

\section{Conclusion}

The MCA can be used to determine the weight of the environmental variables, and can be applied to assess the suitability of oyster production sites. Our findings agree with (Gourmelon et al., 2010; Liang et al., 2015; Li et al., 2015) as this tool can accurately simulate the distribution of site-related environmental parameters. Based on the weight of the variables, the study clearly revealed that production period and oyster culture technique type were significantly associated with microbiological quality. This approach will enable state officials to defend sanitary or public health in order to determine the importance of the variables and the distribution of suitable habitats. It will also help them to adopt various strategies for future action and to control seafood traceability.

\section{References}

Abdi, H., \& Valentin, D. (2007). Multiple correspondence analysis. In N. J. Salkind (Ed.), Encyclopedia of measurement and statistics (pp. 651-657). Texas, USA. Retrieved from https://www.utdallas.edu/ herve/ Abdi-MCA2007-pretty.pdf

APHA (American Public Health Association). (2001). Committee on Microbiological for Foods. Compendium of methods for the microbiological examination of foods (4th ed.). Washington: American Public Health Association. https://doi.org/10.2105/MBEF.0222

Barros, L. M. O., Nazareth, G., Diogo, T., Costa, R. G., Rodrigues, D. P., \& Vieira, R. H. S. F. (2005). Fecal contaminant of the oyster Crassostrea rhizophorae commercialized at Praia do Futuro, Fortaleza, Ceará State. Revista Ciência Agronômica, 36, 285-289. Retrieved from https://www.academia.edu/32688031/ Contaminante_fecal_da_ostra_Crassostrea_rhizophorae_comercializada_na_Praia_do_Futuro_Fortaleza-Ce $\operatorname{ar} \% \mathrm{C} 3 \% \mathrm{~A} 1$

Beth, J. E. (2004). Simple correspondence analysis: A bibliographic review. International Statistical Instititute, 72, 257-284. https://doi.org/10.1111/j.1751-5823.2004.tb00236.x

Brenner, D. J. (1984) Enterobacteriacea. In N. R. Krieg \& J. G. Holtz (Eds.), Bergey's manual of systematic bacteriology. Baltimore, USA.

Christo, S. W., Absher, T. M., Klom, H. E., \& Cruz-Kaed, A. C. (2008). Qualidade da água em área de cultivo de ostras na baía de Guaratuba (Paraná-Brasil). Ciências Biológicas e Saúde, 14, 67-71. https://doi.org/ 10.5212/publicatio\%20uepg.v14i1.484.

Deepanjali, A., Kumar, H. S., Karunasagar, I., \& Karunasagar, I. (2005). Seasonal variation in abundance of Total and Patogenic Vibrio paraheamolyticus bactteriain oysters along the southwest coast of India. Applied and Environmental Microbiology, 71, 3575-3580. https://doi.org/10.1128/AEM.71.7.3575-3580.2005

Edwards, K. J., Gihring, T. M., \& Banfield, J. F. (1999). Seasonal Variations in Microbial Populations and Environmental Conditions in an Extreme Acid Mine Drainage Environment. Applied Environmental Microbiology, 65, 3627-3632. Retrieved from http://aem.asm.org/content/65/8/3627.full.pdf + html

Evangelista-Barreto, N. S., Vieira, R. H. S. F., Carvalho, F. C. T., Torres, R. C. O., Sant'anna, E. S., Rodrigues, D. P., \& Reis, C. M. F. (2006) Aeromonas spp. isolated from oysters (Crassostrea rhizophorea) from a natural oyster bed, Ceará, Brazil. Revista Instituto Medicina Tropical, 48, 129-133. https://doi.org/10.1590/ S0036-46652006000300003

Evans, S., \& Langdon, C. (2006). Direct and indirect responces to selection on individual body weight in the pacific oyter (Crassostrea gigas). Aquaculture, 261, 546-555. https://doi.org/10.1016/j.aquaculture.2006. 07.037

Franco, B. D. G. M., \& Landgraf, M. M. T. (2005). Microbiologia de alimentos (p. 196). São Paulo.

Gourmelon, M., Caprais, M. P., Mieszkin, S., Marti, R., Wéry, N., Jardé, E., ... Pourcher, A. M. (2010). Development of microbial and chemical MST tools to identify the origin of the faecal pollution in bathing and shellfish harvesting waters in France. Water Research, 44, 4812-4824. https://doi.org/10.1016/j.watrres. 2010.07.061

IBGE (Brazilian Institute of Geography and Statistics). (2013). Produção da pecuária municipal. Instituto Brasileiro de Geografia e estatística. Ministério do Planejamento, Orçamento e Gestão: Rio de Janeiro.

Lebart, L., Morineau, A., \& Piron, M. (1995). Statistique exploratoire multidimensionnelle (3rd ed., p. 439). Paris: Dunod. 
Li, T., Li, X., Sun, G., Zhou, Y., Chen, F., Zhong, H., ... Yao, Y. (2015). Assessment of the impacts of trace metals on benthic foraminifera in surface sediments from the northwestern Taiwan Strait. Marine Pollution Bulletin, 98, 78-94. https://doi.org/10.1016/j.marpolbul.2015.07.010

Liang, J., Hua, S., Zeng, G., Yuan, Y., Lai, X., Li, X., ... Yu, X. (2015). Application of weight method based on canonical correspondence analysis for assessment of Anatidae habitat suitability: A case study in East Dongting Lake, Middle China. Ecological Engineering, 77, 119-126. https://doi.org/10.1016/j.ecoleng.2015. 01.016

Maciel, M. L. T., \& Magalhães, A. R. (2009). Saúde de bivalves marinhos: Vigiar para prevenir. Arquivo de Ciências Veterinária e Zoologia, 12, 163-168. Retrieved from http://revistas.bvs-vet.org.br/acvzunipar/ article/view/16196/17062

Mazounia, N., Gaertner, J. C., Deslous-Paolia, J. M., Landreina, S., \& D’oedenberg, M. G. (1996). Nutrient and oxygen exchanges at the water-sediment interface in a shellfish farming lagoon (Thau, France). Journal of Experimental Marine Biology and Ecology, 205, 91-113. https://doi.org/10.1016/S0022-0981(96)02594-4

MPA (Brazilian Ministry of Fisheries and Aquaculture). (2012). Instrução Normativa N7, de maio de 2012. Programa nacional de Controle Higiênico Sanitário de Moluscos Bivalves. Brasília, DF, Seção I.

Oliveira, K. F., Azevedo, R. V., Pereira, M. C., Santos, M. J. M., Carvalho, J. S. O. E., \& Braga, L. G. T. (2014). Uso da ostra Crassostrea rhizophorae como filtro biológico para tratamento de efluentes da carcinicultura. Ciências Agrárias, 35, 2789-2798. https://doi.org/10.5433/1679-0359.2014

Pujalte, M. J., Ortigosa, M., Macián, M. C., \& Garay, E. (1999). Aerobic and facultative anaerobic heterotrophic bacteria associated to Mediterranean oysters and seawater. International Microbiology, 2, 259-266. Retrieved from https://www.researchgate.net/publication/12378186_Aerobic_and_facultative_anaerobic heterotrophic_bacteria_associated_to_Mediterranean_oysters_and_seawater

Ramos, R. J., Pereira, M. A., Miotto, L. A., Faria, L. F. B., Junior, N. S., \& Vieira, C. R. W. (2010). Hygienic sanitary indicator microorganisms in oysters (Crassostrea gigas) and saline waters from sea farms in Baía Sul at Santa Catarina's Island, Brazil. Revista Instituto Adolfo Lutz, 69, 29-37. Retrieved from http://periodicos.ses.sp.bvs.br/pdf/rial/v70n4/v70n4a18.pdf

Sande, D., Melo, T. A., Oliveira, G. S. A., Barreto, L., Talbot, T., Boehs, G. E., \& Andrioli, J. L. (2010). Prospecção de moluscos bivalves no estudo da poluição dos Rios Cachoeira e Santana em Ilhéus, Bahia, Brasil. Jornal Brasileiro de Veterinária e Ciência Animal, 47, 190-196. https://doi.org/10.11606/issn.16784456.bjvras.2010.26854

Santos, P. S., Albuquerque, G. R., Da Silva, V. M. F., Martin, A. R., Marvulo, M. F. V., Souza, S. L. P., ... Silva, J. C. R. (2011). Seroprevalence of Toxoplasma gondii in free-living Amazon River dolphins (Inia geoffrensis) from central Amazon, Brazil. Veterinary Parasitology, 183, 171-173. https://doi.org/10.1016/j.vetpar.2011. 06.007

Silva, A. I. M., Vieira, R. H. S. F., Menezes, F. G. R., Fonteles-Filho, A. A., Torres, R. C. O., \& Sant'anna, E. S. (2004). Bacteria of fecal origin in mangrove oysters in the Cocó river estuary, Ceará state, Brazil. Brazilian Journal of Microbiology, 34, 126-130. https://doi.org/10.1590/S1517-83822004000100021

Soares, L. S. H., Lopez, J. P., Muto, E. Y., \& Giannini, R. (2011). Capture fishery in northern Todos os Santos Bay, tropical southwestern Atlantic, Brazil. Brazilian Journal Oceanography, 59, 61-74. https://doi.org/ 10.1590/S1679-87592011000100005

Yang, Y. Z. H., Yuan, S. X., Mao, M., Liu, Y., Xu, X. E., \& Zhang, F. (2006). Feeding and growth on bivalve biodeposists by deposit feeder Stichopus japonicus Selenka (Echinodermata: Holothuroidea) co-cultured in lantern nets. Aquaculture, 256, 510-520. https://doi.org/10.1016/j.aquaculture.2006.02.005

\section{Copyrights}

Copyright for this article is retained by the author(s), with first publication rights granted to the journal.

This is an open-access article distributed under the terms and conditions of the Creative Commons Attribution license (http://creativecommons.org/licenses/by/4.0/). 